\title{
Land-use effect on hydropedology in a mountainous region of Southeastern Brazil
}

\author{
Efeito do uso do solo na hidropedologia em uma região montanhosa \\ do sudeste do Brasil
}

\author{
Leandro Campos Pinto ${ }^{1 *}$, Carlos Rogério de Mello², Lloyd Darrell Norton ${ }^{3}$, \\ Sérgio Henrique Godinho Silva', Luís Renato Silva Taveira ${ }^{1}$, Nilton Curi ${ }^{1}$
}

\author{
'Universidade Federal de Lavras/UFLA, Departamento de Ciência do Solo/DCS, Lavras, MG, Brasil \\ 2Universidade Federal de Lavras/UFLA, Departamento de Engenharia/DEG, Lavras, MG, Brasil \\ ${ }^{3}$ Purdue University/USDA-ARS, National Soil Erosion Research Laboratory, West Lafayette, Indiana, USA \\ *Corresponding author: leandcampos@yahoo.com.br \\ Received in January 27, 2017 and approved in April 24, 2017
}

\begin{abstract}
In Brazil, the Mantiqueira Range, southeastern region, shelters the last remnants of the ecologically important Upper Montane Tropical Forest. since extensive exploration that has been taking place in this biome for decades, the influence of land-use changes on hydropedology in these areas must be investigated once major land-use changes have been observed. This study aims to evaluate the land-use influence on soil drainable porosity (SDP) in a headwater watershed located in the Mantiqueira Range region, and to validate the proposed methods based on micromorphological and hydrological indicators. The native vegetation of the study area is Atlantic forest that occupies $62 \%$ of the area, and the remaining $38 \%$ has been used for pasture. Thirty nine combinations of environmental variables were tested, each one generating a map for predicting SDP. The performance of the spatial prediction of SDP was assessed using $20 \%$ of the data from the total number of samples collected throughout the watershed. The least values of SDP are due to the process of removal of native forest and replacement by pasture. Areas with high to moderate SDP are associated with native forest fragments demonstrating the effects of the Atlantic Forest on the water infiltration and groundwater recharge processes, given by the greater contribution of baseflow in a forested catchment located within the studied watershed. The analysis of soil micromorphological images provided useful supporting information on the soil porosity system and along with hydrological properties of the watershed helped understand the SDP behavior on subsurface and groundwater storage capacity.
\end{abstract}

Index terms: Upper montane tropical forest; ecological services; mapping modeling; geomorphons.

\section{RESUMO}

No Brasil, a Serra da Mantiqueira, abriga um dos últimos remanescentes da Floresta Tropical de Altitude. Devido a grande exploração que vem ocorrendo neste bioma há décadas, a influência na hidropedologia decorrente das mudanças do uso do solo deve ser investigada. 0 objetivo deste estudo foi avaliar a influência do uso do solo na porosidade drenável do solo (PDS) em uma bacia hidrográfica localizada na região da Serra da Mantiqueira e validar os métodos propostos com base em indicadores micromorfológicos e hidrológicos. A vegetação nativa da área de estudo é a Mata Atlântica que ocupa $62 \%$ da área, e com os 38\% restantes utilizados para pastagem. Trinta e nove combinações de variáveis ambientais foram testadas, cada uma gerando um mapa para predizer a PDS. O desempenho da predição espacial da PDS foi avaliado utilizando $20 \%$ dos dados do número total de amostras coletadas em toda a bacia hidrográfica. Os menores valores de PDS são devidos ao processo de remoção de floresta nativa e substituição por pastagem. Áreas com altos a moderados valores de PDS estão associadas a fragmentos de florestas nativas que demonstram os efeitos da Mata Atlântica nos processos de infiltração de água e de recarga de água subterrânea na região da Mantiqueira, dada a maior contribuição do fluxo base em áreas florestadas. A análise micromorfológica do solo forneceu informações úteis sobre o sistema poroso do solo e as propriedades hidrológicas da bacia hidrográfica, ajudando a entender o comportamento da PDS e a capacidade de armazenamento em subsuperfícíe.

Termos para indexação: Floresta tropical de altitude; serviços ecológicos; modelo de mapeamento; geomorphons.

\section{INTRODUCTION}

Population growth, inadequate soil management and climate changes and variability are the most important elements that have effected the critical zone, becoming water increasingly scarce in mountainous tropical regions around the world. Climate variability has increased the occurrence of extreme events globally, like severe storms and droughts (Stott, 2016). The soil is the natural skin on Earth that has the ability to buffer these events and store water on the landscape for use in many ecologic and human functions. 
The effects on hydrology of native forest and reforestation of degraded lands in the humid tropics have implications for local and regional ecological services, but such issues have been relatively less studied when compared to the impacts of forest conversion to pasture and cropped sites (Mello; Curi, 2012; Pinto; Mello; Ávila, 2013; Pinto et al., 2016). Since these impacts need to be better understood, the knowledge of the relationship between pedology and hydrology (hydropedology) is an important tool for the field of soil and water conservation.

Hydropedology is the interweavement of Soil Science and Hydrology and its application is quite wide within the various branches of knowledge of both sciences (Mello; Curi, 2012), subsidizing the interface between the hydrosphere and the pedosphere (Lin, 2010; Lin, 2012). This field of investigation has great importance for the understanding the critical zone (zone that goes from the canopy to the base of the aquifer) wherein occurs the main processes associated with the hydrological cycle, the vegetative cover and their relationships with the atmosphere, pedosphere, hydrosphere and the lithosphere (Lin, 2010; Mello; Curi, 2012). Therefore, hydropedology has fundamental importance for understanding the processes of groundwater recharge in environments like the Upper Montane Cloud Forest in the Mantiqueira Range, because the soil in this area is an essential element in regulating water cycle functioning, and storage and transmission of water into the saturated zone of the watershed (Pinto et al., 2015a).

Since several springs originate from the mountainous environment, its protection has become fundamental to keep the ecological function balanced from anthropic interferences and degradation. In this kind environment, we can find upper montane forest catchments, which in turn play an important role in water cycling since they are capable of managing rainwater, allowing it to be stored and released slowly into the water courses throughout the year (Pinto et al., 2015a; 2016).

It has been demonstrated that upper montane forests catchments with minimal land cover disturbance will function to store water in subsurface and ground systems due to their ability to infiltrate water, and attenuate rainfall intense due to having good soil physical properties (Alvarenga et al., 2016; Ávila et al., 2014; Menezes et al., 2009; Pinto et al., 2015a; 2016), like high soil drainable porosity. On the contrary, highly disturbed montane catchments that have been submitted to minimal conservation practices can present reduced ability for water infiltration leading to increased overland flow.
In Brazil, an important headwater region that encompasses upper forest catchments (critical zone hydrology) is the Mantiqueira Range Region (MRR), located in southeastern part of the country. Many rivers originate from the MRR which also feed important hydroelectric power plant's reservoirs for the country (Beskow et al., 2009; Viola et al., 2014). In MRR, we can find the last remnants of upper Atlantic Forest in Brazil. Generally, this biome is the richest in species diversity, comprising up to $8 \%$ of the total species in the world and a great number of endemic species (Myers et al., 2000). Unfortunately, despite such great diversity, the Atlantic Forest is one of the most threatened forest's ecosystems on the planet (Colombo; Joly, 2010; Myers et al., 2000). It is estimated that the Atlantic Forest originally occupied over 1.48 million $\mathrm{km}^{2}$ in Brazilian territory (Ribeiro et al., 2009), but now, only $7 \%$ of the original area exist mostly as fragmented remnants distributed over areas with difficult access, such as mountainous regions (Vieira et al., 2008). Taking into consideration these features, MRR should be considered a priority area for conservation in Brazil.

There is a consensus that deforestation of native forests has interfered with the maintenance of water supply, as there is a decreasing in watersheds ability for water infiltration and thus natural regularization of flows. Soils with degraded structure tend to have increased bulk density and consequently a decrease in soil porosity and its continuity, which also affects water movement in the soil profile, since those soil attributes are closely related to soil-water dynamics (Pinto et al., 2015a). In this context, deforestation in the MRR has caused a rapid reduction of the natural regulation of streamflows, leading to water scarcity, with climate drought events becoming more acuter (Menezes et al., 2009; Viola et al., 2015).

More importantly, the influence of land-use changes on hydropedology must be investigated in this region since major land-use changes have been observed in recent years. It is further necessary for the comprehension of soil physical properties and their relationship to hydrologic function on the landscape highlighting the swap in land-use for forests replaced by low productivity pastures (Salemi et al., 2013). In addition, another aspect that influences the hydropedology is the landscape shape. Therefore, the landform indicators become important tools for understanding the relationships between soil properties and landscape (Libohova et al., 2016; Pinto et al., 2016; Silva et al., 2016b).

Geomorphons is a recent computational tool developed by Jasiewicz and Stepinski (2013) and has generated good results for soil mapping. This tool has little computational cost and identifies landforms within 
a landscape through a Digital Elevation Model (DEM) analysis utilizing the concept of Local Ternary Patterns (LTP) (Liao, 2010). A local pattern is determined using a neighborhood with size and shape that self-adapts to the local topography (Jasiewicz; Stepinski, 2013). Based on this concept, ten most common types of landforms are identified and some studies have related such a concept to soil properties variability, generating new insights for the hydropedology field of investigation (Pinto et al., 2016; Silva et al., 2016a, b; Toma et al., 2015).

In this sense, the use of new technologies, such as those provided by digital soil mapping (McBratney; Santos; Minasny, 2003) that allows the user to make inferences about hydropedological variability across the landscape by means of land-use changes over time and landforms classification, enable a more complete understanding of the environmental functions (Menezes et al., 2014). Additionally, a more detailed description of soils as promoted by micromorphological analyses as well as the use of hydrological parameters, such as those that influence streamflows, can also increase the level of understanding of the influence of land-use change on pedological properties and indeed on hydrology (Pinto; Mello; Ávila, 2013).
Therefore, the overall hypothesis for this research is that land-use has a strong influence on soil drainable porosity (SDP) in watersheds within headwater environments, like MRR, where the subsurface and groundwater recharge are very sensitive to land-use (Alvarenga et al., 2012; Viola et al., 2013, 2014).

This study aims to evaluate the land-use influence on SDP in a tropical headwater watershed, by means digital soil mapping modeling based on landform classification, soil micromorphology analyses, and hydrological indicators as parameters to validate the hypothesis.

\section{MATERIAL AND METHODS}

\section{Study site}

This study was carried out in Lavrinha Creek Watershed (LCW), a headwater watershed located in Southeastern Brazil, between latitudes $22^{\circ} 6^{\prime} 53.7^{\prime \prime}$ and $22^{\circ} 8^{\prime} 28.1^{\prime \prime} S$ and longitudes $44^{\circ} 26^{\prime} 21.1^{\prime \prime}$ and $44^{\circ} 28^{\prime} 39.2^{\prime \prime} \mathrm{W}$, with an area of 676 ha within the Mantiqueira Range physiographical region. The native vegetation is Atlantic forest, and the land cover includes Atlantic Forest occupying $62 \%$ of LCW in the steepest slopes, whereas, gentler slopes contain degraded pasture in $38 \%$ of the area (Figure 1).

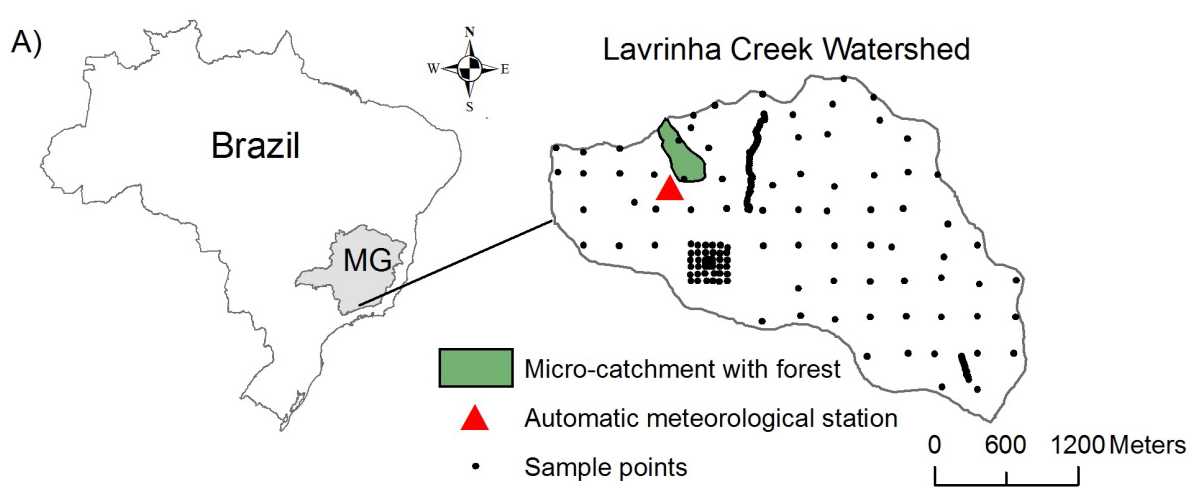

B) Land-use map

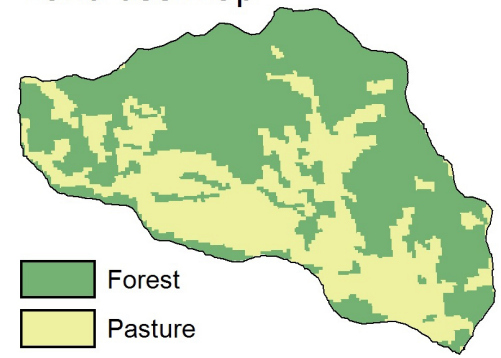

C) Soil map

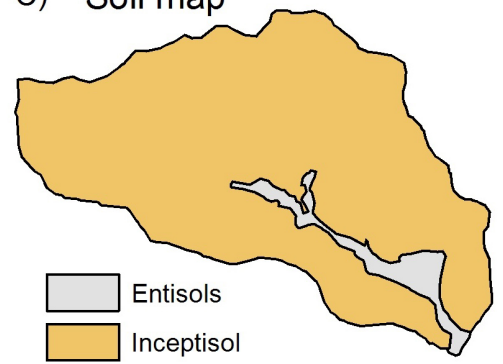

Figure 1: Geographical location and micro-catchment entirely occupied by upper native forest located inside Lavrinha Creek Watershed (A), land-use map (B) and soil map (C) of Lavrinha Creek Watershed, Minas Gerais State (MG), Southeastern Brazil. 
Inceptisols are the main soils in the watershed, covering about $92 \%$ of the area (Menezes et al., 2009) (Figure 1). These are relatively minimally weathered soils that constitute very fragile systems because they have $\mathrm{C}$ horizon near the surface, making them highly susceptible to water erosion (Pinto et al., 2015b; Resende et al., 2014), which is amplified as they are located on very steep slopes. Also, they have very weak blocky structure when dry, but when moist or wet the effects of such structure are not well expressed, and they are very susceptible to crusting, which tends to decrease the low natural water infiltration and, hence, soil water recharge (Pinto et al., 2015a).

\section{Digital elevation model and Terrain attributes}

Terrain attributes (TA) were obtained through the creation of a digital elevation model (DEM) (Figure 2), a continuous raster format representation of the altitude, constituted by pixels of $10 \times 10 \mathrm{~m}$ that inform the elevation of each place on the landscape. In this procedure, planaltimetric maps (1:50,000 scale) and elevation points, available at the Brazilian Geography and Statistics Institution (IBGE) website (http://www.ibge.gov.br), were inserted in ArcGIS software (ESRI) to develop the DEM for LCW area using the Topo to Raster function. The DEM sinks were filled in order to make it
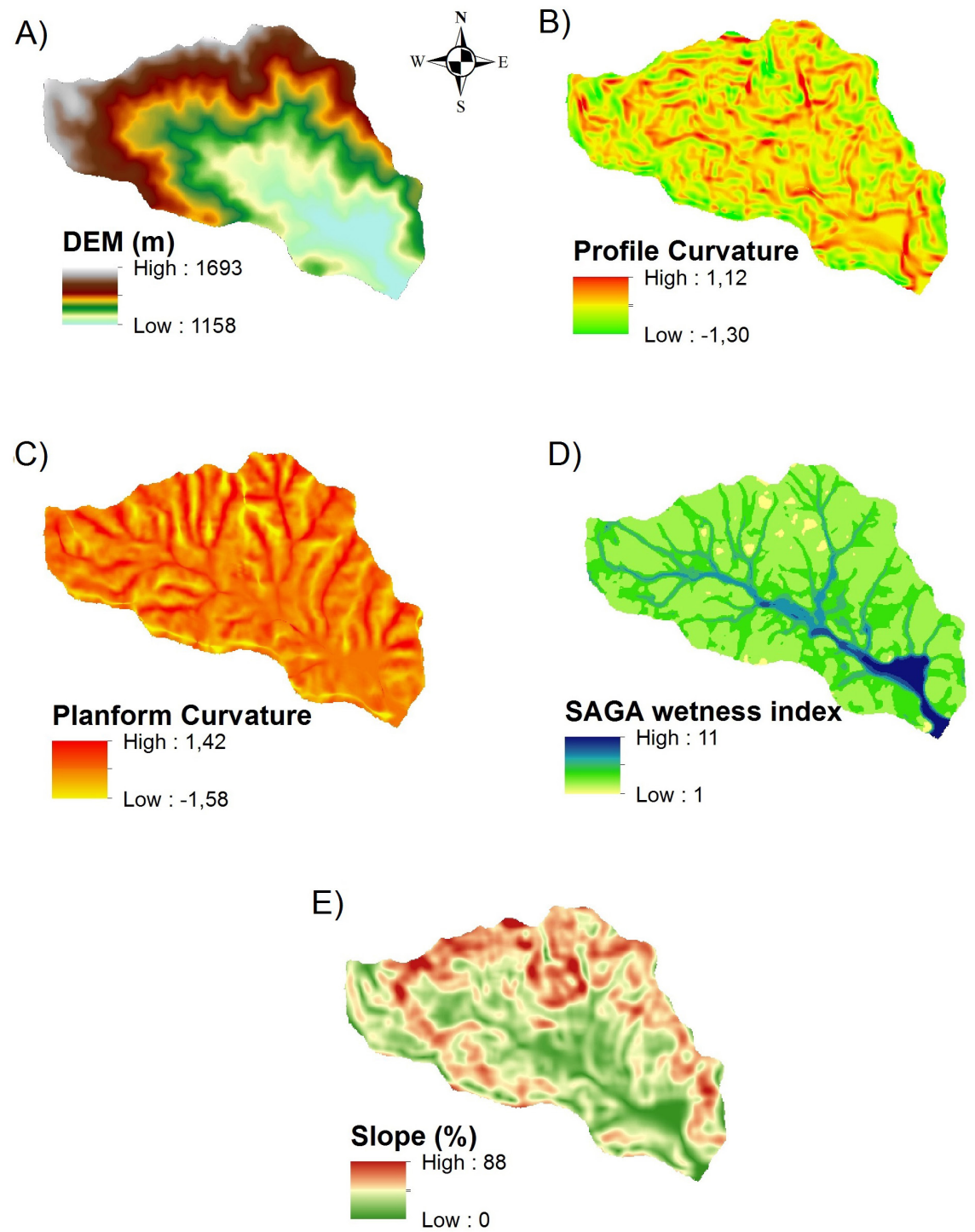

Figure 2: Digital elevation model (DEM) (A) and terrain attributes (TA): profile curvature (B), planform curvature (C), SAGA wetness index (D) and slope (E) for LCW. 
hydrologically consistent (Figure 2). It allowed the creation of other terrain maps derived from the DEM using the software ArcGIS (ESRI) and SAGA GIS (Conrad et al., 2015), such as slope gradient, profile and planform curvatures and SAGA wetness index (SWI) (Figure 2). All these variables are environmental covariates widely used as adequate predictors of soil classes and properties as demonstrated in several studies regarding soil mapping (Adhikari et al., 2014; Brown; McDaniel; Gessler, 2012; Hengl et al., 2015; Silva; Santos; Marques, 2014, 2016a, b, c; Vaysse; Lagacherie, 2015).

\section{Landform classification}

Geomorphons is a recent computational tool developed by Jasiewicz and Stepinski (2013), which has little computational cost and identifies landforms within a landscape through a Digital Elevation Model (DEM) analysis. Geomorphons was derived from DEM using nine different look up distances (L) $(5,7,10,15,20,25,30,40$, and 50 cells), which correspond to the number of cells (pixels) in the radius of the circumference around a cell of interest and was performed using GRASS GIS 7.0 (Neteler; Mitasova, 2008). The most frequent and common landform elements from a typical terrestrial landscape that this tool can identify are flat, summit, ridge, shoulder, spur, slope, hollow, footslope, valley, and depression (Jasiewicz; Stepinski, 2013) (Figure 3).

\section{Soil Drainable Porosity (SDP) mapping model}

SDP values were obtained from soil samples collected throughout the watershed in a sampling scheme as illustrated in Figure 1a. Its calculation is based on the difference between soil moisture saturation and soil moisture at field capacity (Mello et al., 2002), making up a total of 193 samples. These samples were divided into two groups: one for calibration and another for validation. Data from the calibration group ( $80 \%$ of the data) were used to generate SDP maps, while for validation, the remaining $20 \%$ of the data were used.

SDP map for LCW was modeled based on a digital soil mapping approach that combines expert knowledge, for developing guiding rules of soil classes and properties, and fuzzy logic which is embedded as an ArcGIS 10.1 (ESRI), being an extension named ArcSIE (Soil Inference Engine) (Shi et al., 2009). ArcSIE is an expert knowledge-based inference tool designed for creating soil maps based on fuzzy logic (McKay et al., 2010), setting a similarity value
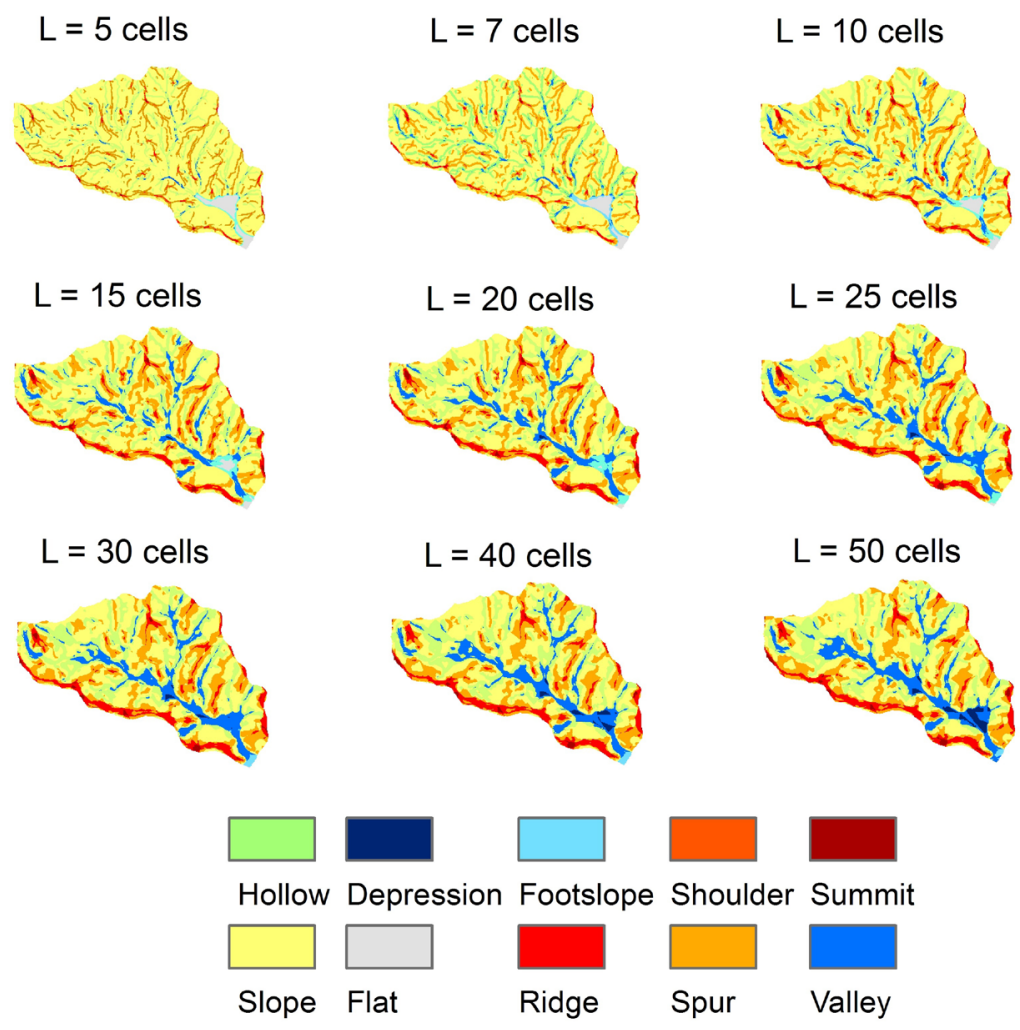

Figure 3: Geomorphons for Lavrinha Creek Watershed with different look up distances $(L)(5,7,10,15,20,25,30$, 40 , and 50 cells). 
for each pixel through comparison of each pixel to an ideal condition (rules). The greater the similarity between the pixel condition (terrain information) and the rule for a soil class, the higher the value assigned to each pixel, ranging from 0 (no similarity) to 1 (high similarity). This approach is named Rule-Based Reasoning (RBR) inference method and was implemented in ArcSIE for calculating fuzzy membership values and, thus, generating fuzzy membership maps for the entire area, which, in turn, are referred to as optimality functions because they define the relationships between the values of an environmental covariate and a soil class (rule) (Menezes et al., 2013). Then, these fuzzy membership maps are combined into one final hardened map, in which only the soil class that is likely to occur at each pixel (based on the rules and the similarity vectors) is assigned to that pixel, which means classes with the highest membership values (Menezes et al., 2014). From this soil class map, a soil property map can be created.

The fuzzy membership maps were produced in four different ways: a) based on solely on terrain attributes, according to rules among values of the terrain information (DEM, slope, plan and profile curvatures, and SWI) obtained from Menezes et al. (2014) to generate a soil class map and then a soil SDP map; b) based on a land-use map for LCW; c) based on Geomorphons maps created at nine different look up distances; and d) using combinations between the land-use map, terrain attributes and the Geomorphons generated at nine look up distances. The nominal function was used to produce membership maps from the land-use and Geomorphons fuzzy, in which each environmental feature (forest, pasture, and Geomorphons types) became a membership map.

Thirty-nine combinations of the environmental variables (Terrain Attributes (TA), land-use (LU) and Geomorphons (Geom) at nine different look up distances (L) $(5,7,10,15,20,25,30,40$, and 50 cells) were tested, each one generating a map for predicting DP. These maps required a typical SDP value for each membership map to be generated and this value was obtained from the calculation of the mean value of SDP from the samples collected throughout the watershed, as illustrated in Figure 1a. In sequence, the continuous variation of this soil property resulted in a SDP map derived from similarity vectors, by the following formula in ArcSIE (Zhu et al., 1997) (Equation 1):

$$
\mathrm{V}_{\mathrm{ij}}=\frac{\sum_{\mathrm{k}=1}^{\mathrm{n}} \mathrm{S}_{\mathrm{ij}}^{\mathrm{k} *} \mathrm{~V}^{\mathrm{k}}}{\sum_{\mathrm{k}=1}^{\mathrm{n}} \mathrm{S}_{\mathrm{ij}}^{\mathrm{k}}}
$$

where, $V(i j)$ is the estimated SDP value at location $(i j), \mathrm{S}_{\mathrm{ij}}^{\mathrm{k}}$ is the final fuzzy membership value at $(i j)$ for environmental variable $\mathrm{k}, V^{k}$ is a typical value (mean) of environmental variable $k$, and $n$ is the total number of prescribed environmental variables for the area.

The performance of the 38 SDP maps (resulted from the combination of the environmental variables) was assessed using $20 \%$ of the data, as previously mentioned, and used for comparison purposes among the 9 different look up distances by comparing the predicted SDP values with the correspondent real values of the validation set. Statistical parameters such as $\mathrm{R}^{2}$, adjusted $\mathrm{R}^{2}$, mean absolute error (MAE) (Equation 2), and root mean square of error (RMSE) (Equation 3) were calculated in R software (R Development Core Team) for comparison purposes.

$$
\begin{aligned}
& M A E=\frac{1}{n} \sum_{i=1}^{n}|e i-m i| \\
& R M S E=\sqrt{\frac{1}{n} \sum_{i=1}^{n}(e i-m i)^{2}}
\end{aligned}
$$

where, $n$ is the number of observations, $e i$ is the estimated value of the SDP and the $m i$ is its measured value.

\section{Micromorphological analyses}

Micromorphological studies were carried out to detail SDP, at a microscope scale. The pore system was characterized using image analysis of thin sections from undisturbed soil samples collected at depths of 0-20 cm and $20-50 \mathrm{~cm}$, encompassing both $\mathrm{A}$ and $\mathrm{B}$ horizons, respectively, using a Kubiena box. These samples were air-dried and subsequently slowly dried in an oven at the following temperatures $40{ }^{\circ} \mathrm{C}, 60^{\circ} \mathrm{C}$ and $100{ }^{\circ} \mathrm{C}$ for 24 hours, to minimize cracking due to rapid drying. The samples were then impregnated with an epoxy resin and de-aerated under vacuum (Castro et al., 2003) for three days to minimize air bubbles, and then heated at $100{ }^{\circ} \mathrm{C}$ for 4 hours, and $140{ }^{\circ} \mathrm{C}$ for 4 hours for hardening and curing. The hardened resin blocks were cut, polished and mounted onto glass slides with de-aerated Hillquist ${ }^{\circledR}$ epoxy resin $7 \mathrm{~A} / 3 \mathrm{~B}$, and heated for $1 \mathrm{~min}$ at $105^{\circ} \mathrm{C}$. Finally, the mounted blocks were sectioned and polished to the ideal thickness of $30 \mu \mathrm{m}$ for micromorphological analysis (Murphy, 1986), and analyzed with a petrographic microscope, in which images (micrographs) were taken. 
Once the images were obtained, they were classified into two categories, porosity and soil matrix, using ArcGIS 10.1 (ESRI). The toolbar image classification used for that performs a maximum likelihood classification on a set of raster bands and creates a two class (porosity and soil matrix) raster as output. It allowed the analyses of the percentage of the area of the image occupied by pores, their type, and continuity as well as soil matrix, which are associated with soil drainage.

\section{Hydrologic validation}

In order to validate and better understand the SDP behavior, some hydrological indicators were performed based on comparison of the base flow (BF) behavior in a micro-catchment entirely occupied by upper native forest located inside LCW (MFO) and in LCW as a whole, as the latter has its hydrology influenced by other land-uses (Figure 1). BF is related to water storage in the underground saturated zone of the watersheds and, thus, primarily is linked to the SDP behavior. In this sense, every change on pedologic properties will influence in the hydrologic outputs of these watersheds.

MFO covers a drainage area of about 16 ha entirely occupied by Dense Ombrophilous Forest, which is a typical remnant of the Atlantic Forest of the Mantiqueira Range region (Oliveira Filho et al., 2006). This microcatchment has an average slope of $35 \%$ and the altitude varies between $1,475 \mathrm{~m}$ and $1,685 \mathrm{~m}$ above sea level.

Weather data sets for LCW and MFO were obtained between June/2009 and September/2011 with one Campbell automatic meteorological station installed in a clear-cut area outside MFO (Figure 1). Streamflows were monitored using a Parshall flume attached to a water level logger (model WL16 Global Water Instrumentation, California, USA, with the precision of $\pm 0,1 \%$ ). For LCW, the same device was employed, however, building a gauging station and fitting a stage-discharge curve for the section. Both stations have provided a discharge value every 60 minutes.

Base flow $(\mathrm{Db})$ was studied throughout the hydrological years of 2009/2010 and 2010/2011, considered as a hydrological year was the period between September of a year to August of the subsequent year as the region is strongly characterized by a rainy summer and a dry winter (Mello et al., 2012). Its characterization was made based on the separation from streamflows (overland flow and base flow). For that, daily streamflow observations were accounted from 2009 to 2011 were used and the Barnes' method was applied allowing the characterization of the hydrograph recession (Barnes, 1939; Durães; Mello, 2013; Hingray; Picouet; Musy, 2014). This method is based on the identification of inflection points in the runoff $(\mathrm{R})$ hydrographs, considering an exponential behavior for the base flow (Equation 4). From the separation of the base flow, it is possible to account for it in relation to the total runoff $(\mathrm{Db} / \mathrm{R})$, which is one of the most important hydrology indicators used for comparing watersheds.

Recession coefficient was defined following the fundamentals of the Maillet equation (Dewandel et al., 2003) which has an exponential mathematical behavior:

$$
Q_{t}=Q_{0} \exp (-\alpha . t)
$$

where, $\mathrm{Q}_{0}$ is the initial baseflow rate, $\mathrm{Q}_{t}$ is the baseflow rate at time $t$ (daily) and $\alpha\left(\right.$ day $\left.^{-1}\right)$, the recession coefficient, which is a physical property of the aquifer. This coefficient was obtained by taking into account the baseflow observed during the hydrograph recession throughout the dry period, which was better characterized between June and August (end of the hydrological year) as this period allows for characterization of the acute dry period in the region (Coelho et al., 2016).

The recession coefficient $(\alpha)$ indicates the production rate of the base flow that represents the part of the streamflow which is predominantly maintained by groundwater restitution (Silva; Bacellar; Fernandes, 2010). In this model, as the baseflow has a rate exponential decrease (Equation 4), the greater $\alpha$, in absolute values, the closer the $\mathrm{Q}_{\mathrm{t}}$ and $\mathrm{Q}_{0}$ values will be, or the greater natural regulatory capacity of the watershed, with greater amount of water stored, providing streamflow even during the driest periods of the year.

Having this point in mind, we understand that two hydrological years data, without gaps in the data series, can qualitatively reflect the impacts from these two different land-uses (native forest and pasture) in SDP behavior. The hydrologic indicators considered were the ratio between baseflow/runoff $(\mathrm{BF} / \mathrm{R})$ and overland flow/ runoff $(\mathrm{OF} / \mathrm{R})$, allowing to quantify the participation of baseflow as it is a consequence of groundwater subsurface saturated zone recharge, meaning it is affected by SDP. In addition, the coefficient of depletion for both catchments was also evaluated as it allows the understanding of how the saturated zone behaves in terms of drainage of water storage, being another relevant hydrology indicator. 


\section{RESULTS AND DISCUSSION}

\section{Spatial distribution of soil drainable porosity}

Table 1 shows the $\mathrm{R}^{2}, \mathrm{R}_{\text {adj }}^{2}$, MAE and RMSE regarding the performance of the predictive methods for SDP at LCW.

Table 1: $R^{2}, R_{\text {adj' }}^{2}$ MAE and RMSE for assessment of predictive methods performance of SDP at LCW.

\begin{tabular}{|c|c|c|c|c|}
\hline \multirow{2}{*}{ Methods } & \multicolumn{4}{|c|}{ Parameters } \\
\hline & $\mathrm{R}^{2}$ & $\mathrm{R}_{\text {adj }}^{2}$ & MAE & RMSE \\
\hline LU & 0.36 & 0.34 & 4.19 & 6.308 \\
\hline TA & 0.05 & 0.02 & 6 & 7.576 \\
\hline$T A+L U$ & 0.51 & 0.5 & 4.18 & 6.117 \\
\hline Geom $_{\mathrm{L} 5}$ & 0.01 & -0.02 & 6.1 & 7.861 \\
\hline Geom $_{\mathrm{L} 7}$ & 0.06 & 0.03 & 6.02 & 7.849 \\
\hline Geom $_{\mathrm{L} 10}$ & 0.05 & 0.02 & 6.2 & 7.917 \\
\hline Geom $_{\mathrm{L} 15}$ & 0.12 & 0.09 & 5.9 & 7.31 \\
\hline Geom $_{\mathrm{L} 20}$ & 0.14 & 0.12 & 5.71 & 7.139 \\
\hline Geom $_{\mathrm{L} 25}$ & 0.14 & 0.12 & 5.72 & 7.155 \\
\hline Geom $_{\text {L30 }}$ & 0.07 & 0.04 & 6.04 & 7.595 \\
\hline Geom $_{\llcorner 40}$ & 0.06 & 0.03 & 5.91 & 7.753 \\
\hline Geom $_{\text {L50 }}$ & 0.03 & 0.01 & 6.14 & 8.12 \\
\hline Geom $_{\mathrm{L5}}+\mathrm{TA}$ & 0.02 & 0 & 6.05 & 7.685 \\
\hline Geom $_{\mathrm{L} 7}+\mathrm{TA}$ & 0.07 & 0.04 & 5.86 & 7.525 \\
\hline Geom $_{\mathrm{L} 10}+\mathrm{TA}$ & 0.05 & 0.02 & 6.03 & 7.674 \\
\hline $\mathrm{Geom}_{\mathrm{L} 15}+\mathrm{TA}$ & 0.12 & 0.09 & 5.76 & 7.218 \\
\hline Geom $_{\mathrm{L} 20}+\mathrm{TA}$ & 0.14 & 0.11 & 5.63 & 7.132 \\
\hline Geom $_{\mathrm{L} 25}+\mathrm{TA}$ & 0.14 & 0.11 & 5.63 & 7.133 \\
\hline $\mathrm{Geom}_{\mathrm{L} 30}+\mathrm{TA}$ & 0.07 & 0.05 & 5.83 & 7.44 \\
\hline Geom $_{\mathrm{L} 40}+\mathrm{TA}$ & 0.07 & 0.05 & 5.72 & 7.472 \\
\hline Geom $_{L 50}+$ TA & 0.05 & 0.02 & 5.88 & 7.682 \\
\hline Geom $_{\mathrm{L5}}+\mathrm{LU}$ & 0.46 & 0.45 & 4.43 & 5.87 \\
\hline $\mathrm{Geom}_{\mathrm{L} 7}+\mathrm{LU}$ & 0.48 & 0.47 & 4.34 & 5.676 \\
\hline $\mathrm{Geom}_{\mathrm{L} 10}+\mathrm{LU}$ & 0.48 & 0.47 & 4.26 & 5.692 \\
\hline $\mathrm{Geom}_{\mathrm{L} 15}+\mathrm{LU}$ & 0.56 & 0.55 & 4.15 & 5.407 \\
\hline $\mathrm{Geom}_{\mathrm{L} 20}+\mathrm{LU}$ & 0.6 & 0.59 & 4.37 & 5.569 \\
\hline $\mathrm{Geom}_{\mathrm{L} 25}+\mathrm{LU}$ & 0.6 & 0.59 & 4.04 & 5.339 \\
\hline $\mathrm{Geom}_{\mathrm{L} 30}+\mathrm{LU}$ & 0.52 & 0.5 & 4.16 & 5.618 \\
\hline $\mathrm{Geom}_{\mathrm{L} 40}+\mathrm{LU}$ & 0.5 & 0.49 & 3.92 & 5.623 \\
\hline
\end{tabular}

Table 1: Continuation..

\begin{tabular}{ccccl}
\hline \multirow{2}{*}{ Methods } & \multicolumn{4}{c}{ Parameters } \\
\cline { 2 - 5 } & $\mathrm{R}^{2}$ & $\mathrm{R}_{\text {adj }}^{2}$ & $\mathrm{MAE}$ & $\mathrm{RMSE}$ \\
\hline Geom $_{\mathrm{L} 50}+\mathrm{LU}$ & 0.44 & 0.43 & 4.03 & 5.79 \\
Geom $_{\mathrm{L} 5}+\mathrm{LU}+\mathrm{TA}$ & 0.43 & 0.42 & 4.59 & 6.112 \\
Geom $_{\mathrm{L}+}+\mathrm{LU}+\mathrm{TA}$ & 0.46 & 0.45 & 4.41 & 5.918 \\
Geom $_{\mathrm{L} 10}+\mathrm{LU}+\mathrm{TA}$ & 0.44 & 0.42 & 4.5 & 5.991 \\
Geom $_{\mathrm{L} 15}+\mathrm{LU}+\mathrm{TA}$ & 0.51 & 0.49 & 4.38 & 5.75 \\
Geom $_{\mathrm{L} 20}+\mathrm{LU}+\mathrm{TA}$ & 0.53 & 0.51 & 4.27 & 5.707 \\
Geom $_{\mathrm{L} 25}+\mathrm{LU}+\mathrm{TA}$ & 0.53 & 0.51 & 4.3 & 5.707 \\
Geom $_{\mathrm{L} 30}+\mathrm{LU}+\mathrm{TA}$ & 0.47 & 0.46 & 4.38 & 5.914 \\
Geom $_{\mathrm{L} 40}+\mathrm{LU}+\mathrm{TA}$ & 0.45 & 0.44 & 4.22 & 5.912 \\
Geom $_{\mathrm{L} 50}+\mathrm{LU}+\mathrm{TA}$ & 0.41 & 0.39 & 4.26 & 6.034 \\
\hline
\end{tabular}

According to these statistical indicators, since the greater the $\mathrm{R}^{2}$ and adjusted $\mathrm{R}^{2}$ and the lower the MAE and the RMSE the better the prediction, the method that combines Geomorphons with look up distance of 25 cells $\left(\mathrm{Geom}_{\mathrm{L} 25}\right)$ and land-use (LU) was the most efficient to predict SDP at LCW, with the greatest $\mathrm{R}^{2}$ and $\mathrm{R}_{\text {adj }}^{2}$, and RMSE and MAE closer to zero.

It can be seen that, among the several prediction methods tested for SDP prediction, when land-use was taken into account, the precision of the model increased significantly (Table 1) in comparison to methods that only considered the TA and/or Geomorphons. Therefore, there is a clear and strong relationship between land-use and SDP. This brings a new insight to the effects that land-use changes may cause on the environment, mainly in critical zones such as the MRR.

Regarding the variables used for different prediction methods, the association of land-use with Geomorphons improved the SDP predictions. Silva et al. (2016b) studying the same area found a strong relationship between Geomorphons and soil types regardless of pixel size and look up distance for Geomorphons calculation. Other studies have successfully used models applying Geomorphons to predict soil properties (e.g. Libohova et al., 2016; Pinto et al., 2016). However, in agreement with the result of this study is that the Geomorphons solely could not accurately predict the soil property SDP, Toma et al. (2015) found that Geomorphons in association with slope gradient better explained the relationships of landform and soil organic carbon than only Geomorphons.

Because the method that combines Geom $_{\mathrm{L} 25}$ and land-use was the most efficient, it was used to create the spatial distribution of SDP for LCW (Figure 4). 


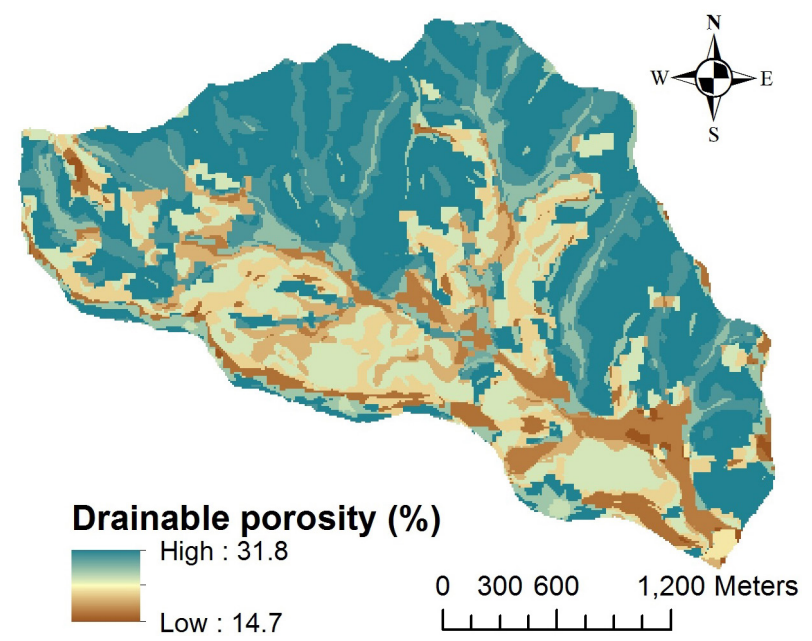

Figure 4: Spatial distribution of soil drainable porosity predicted using the method that combines Geomorphons with look up distance of 25 cells and land-use.

In situ, SDP values ranged from 6 to $53 \%$ with an average of $27 \%$. Analyzing the values obtained in the field, it was possible to observe a clear distinction between those obtained under native forest areas and those obtained in areas with human intervention (Figure 4). In the northern LCW, which is covered by native forest, it was observed the greater SDP values (average $31.85 \%$ ) than for $\mathrm{LCW}$ as a whole. In contrast, the lower SDP values (average 14.48\%) were found in areas with a predominance of pastures in the central and southwestern areas of the watershed. These results are better observed when SDP map is compared to the watershed land-use map (Figure 1). It's evident that areas that show greater SDP are covered by native forest, indicating that this land-use has a great influence on the SDP values in this watershed.

On the other hand, the anthropic action tends to affect the soil permeability, thus, preserved areas like native forests have greater potential for infiltration, promoting a reduction in overland flow and reduce sediment transport. Therefore, the lowest values of SDP at areas under pasture are due to the process of withdrawal and replacement of native forest for this type of land-use. This behavior can be associated with the characteristics of Atlantic Forest in mountainous region, like the MRR, which has a thick litter layer, low soil bulk density, high organic carbon content and greater biological activities when compared to pasture, whose physiographic characteristics do not favor water infiltration (Menezes et al., 2009). The presence of native forests in an advanced stage of development provides better conditions for the development and maintenance of gravitational pores with higher SDP, and formation of preferential flows throughout the soil profile (Bonell et al., 2010; Mello; Curi, 2012; Pinto et al., 2015b). Therefore, even the partial deforestation can bring substantial changes in patterns of hydrological response of the headwater catchments (Wiekenkamp et al., 2016).

Price, Jackson and Parker (2010), in a hydrological study carried out in mountainous catchments, also found that the conversion of native vegetation to agricultural uses reduced soil infiltration and soil-water storage capabilities, resulting in increased surface runoff and reduced subsurface storage. The results of Germer et al. (2010), in study involving land-use change on near-surface hydrological processes in the Amazon Basin, show that conversion of undisturbed forest to pasture increased not only the frequency and volume of stormflow, but also the contributing area and the manner in which the water moves into and through soil towards the drainage channels. Pietola, Horn and Yli-Halla (2005) found a significant difference in water infiltration between trampled and non-trampled soils by cattle, even though the grazing intensity was low.

Therefore, the spatial identification of promising areas in the context of water recharge allows for better land-use planning in order to maintain a sustainable water supply (Viola et al., 2015). Tsui, Chen and Hsieh (2004), researching the relationships between soil properties and slope positions in a lowland rain forest of Southern Taiwan, found an increase of organic carbon and a lower rate of decomposition in the summit forest. Other authors found similar results and stated that these results are mostly linked to the native forest existence, which consists of a system without human activity and provides a greater amount of organic carbon to the environment (Beutler et al., 2002; Rawls et al., 2003).

\section{Background from micromorphological analyses}

To strengthen the findings previously presented in this study, micromorphological analyses of the A and B horizons of the studied soil (Inceptisols) were also conducted aiming to further understand how soil structure was influenced by land-use and thus, SDP and water percolation throughout soil profile (Figure 5).

The micromorphological analysis clearly showed the soil under forest has a much more open and heterogeneous pore structure network. Analyzing the scanned image, soil porosity decreased with depth for both land-uses, ranging from 33 to $52 \%$ in the Inceptisols 
under native forest and from 18 to $21 \%$ in the Inceptisols under pasture. This may be partially due to the greater amount of soil organic matter in the A horizon than in B horizon $(9.2 \%$ and $4 \%$ in horizon $\mathrm{A}$ and $\mathrm{B}$ under forest, respectively, and $4.6 \%$ and $2.9 \%$ in horizon $A$ and $B$ under pasture, respectively). Organic matter is strongly related to the formation of granular structure in the surface horizon, thus, favouring greater drainable porosity in contrast to the blocky structure in the B horizon that tends to promote greater microporosity than drainable porosity when compared to the A horizon (Buol et al., 2011; Resende et al., 2014; Tobiašová, 2011).
Regarding land-use, the Inceptisols under native forest had greater porosity values, which vary from 40 to $55 \%$, according to scanned image area evaluated, greater than those for Inceptisols under pasture in the 0-20 and 20-50 cm depth, respectively. All these results corroborate and strengthen the patterns obtained for drainable porosity analyses (Figure 4).

The knowledge of soil porosity in the Mantiqueira Range region was important to support the sustainable use and conservation of the environment resources and this micromorphological technique has become an important tool for investigating and understanding the hydropedology on the landscape.
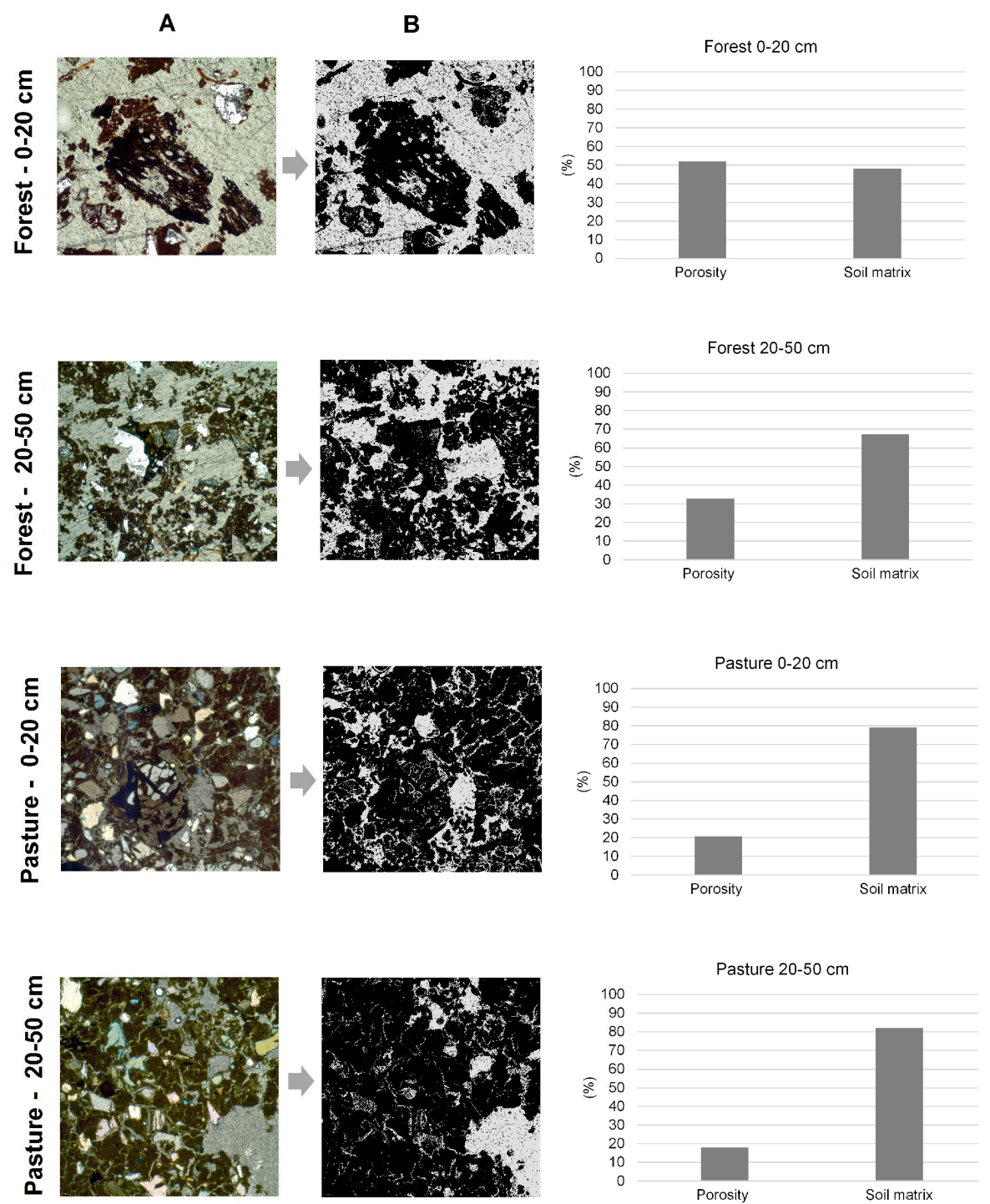

Figure 5: Thin sections of soils under native forest and pasture (at $0-20 \mathrm{~cm}$ and $20-50 \mathrm{~cm}$ depths) (A) and image classified in porosity and soil matrix (B). Frame length is $2.7 \mathrm{~mm}$. All images (A) are under cross-polarized light. 


\section{Validation from hydrological point of view}

To validate from a hydrological point of view SDP is essential as a soil hydrology attribute that strongly influence the soil-water infiltration, and thus, in the catchment hydrology as a whole. This way, some hydrological indicators were also analyzed. Figure 6 presents the observed hydrographs for both LCW as a whole and for MFO sites throughout the hydrological years of 2009/2010 and 2010/2011.
It is possible to observe intra-annual variability of streamflow, highlighted by the peak discharges, being a clear result of the regional climate characteristics (high concentration of rainfall during the summer). Despite the effect of the canopy of the Atlantic Forest in the rainfall intensity, for MFO, we can see a greater oscillation in the hydrograph, with more frequent peak discharge occurrence, including during the dry season as the catchment is much smaller than LCW and the relief is steeper.
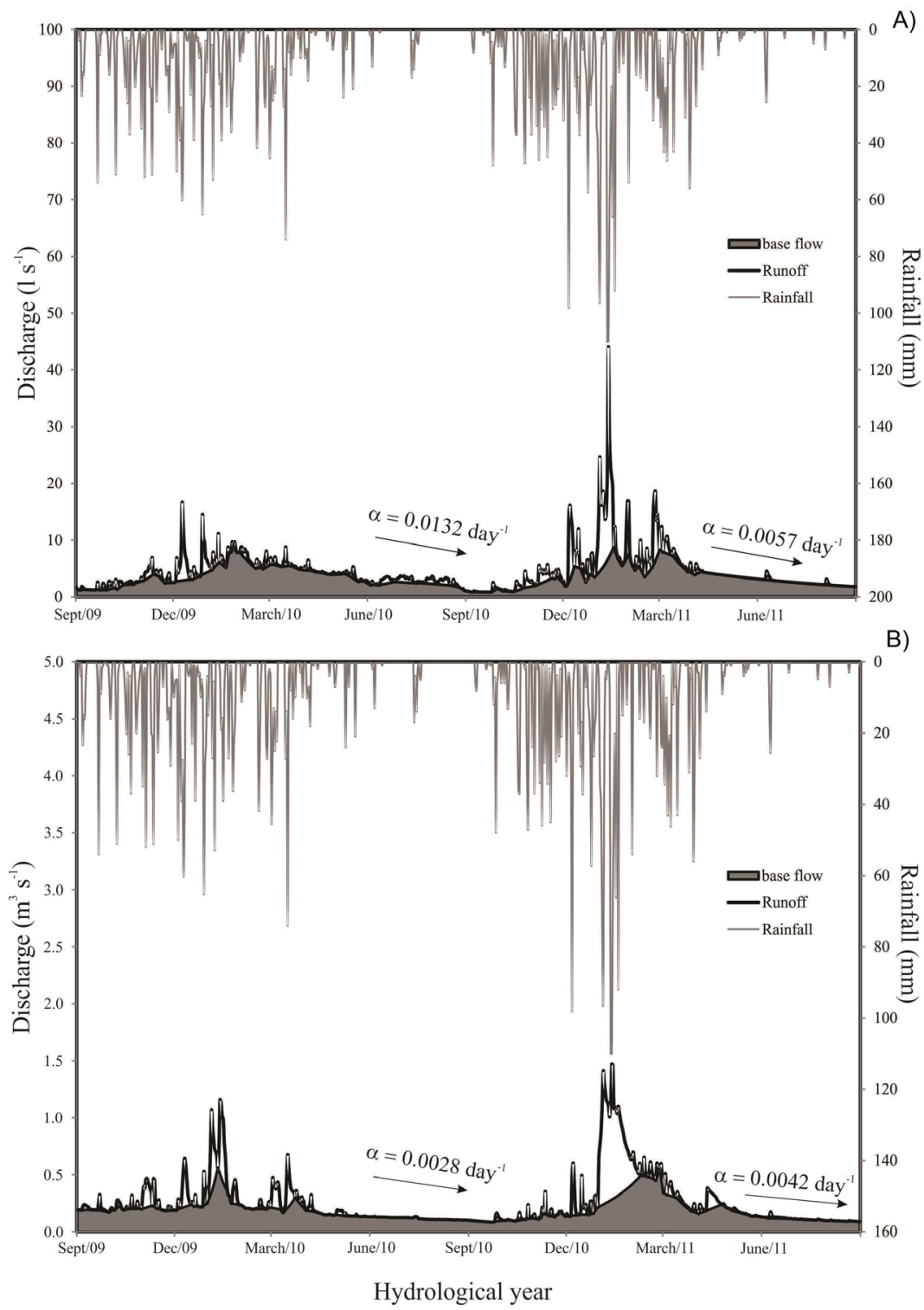

Figure 6: Rainfall, streamflow and base flow estimated at a micro-catchment entirely occupied by native forest (MFO) (A) and Lavrinha Creek Watershed (LCW) (B) during the hydrological years of 2009/2010 and 2010/2011 (a = coefficient of recession). 
It was observed that there was a greater concentration of rainfall in the 2010-2011 hydrological year, with accentuated peak discharges in January/2011 as a consequence of the events with an intensity greater than $40 \mathrm{~mm} \mathrm{~h}^{-1}$, meaning more favorable conditions for the occurrence of overland flow at both studied sites. Although these intense rainfall events, areas with native forest and higher SDP values had better conditions for water percolation in the soil profile compared with those areas with lower SDP which is linked to the degraded pasture. In other words, in the MFO, there are more favorable conditions for infiltration of water into the soil, promoting recharge to the sub-surface (from A horizon and the saprolite) layer or even for aquifers located below this saturated zone, as SDP is much greater in relation to the entire LCW. Thus, we can link this more significant occurrence of baseflow in this catchment (in relation to LCW as a whole) (Figure 6) to the greater SDP values under Atlantic Forest conditions (Figure 4).

In general, for both years (2009/2010 and 2010/2011) a greater amount of baseflow could be observed in the MFO, meaning that there were better conditions for infiltration and, consequently, greater water yield capacity over time.

Table 2 presents precipitation, runoff, overland flow, base flow, and recession coefficient in the hydrological years monitored for $\mathrm{LCW}$ and $\mathrm{MFO}$, extracted from hydrograph analyses presented in Figure 6.

At both hydrological sites, the hydrological year of 2009/2010 generated greater participation to the baseflow as a consequence of a better temporal distribution of rainfall in summer, with lower rainfall intensity events. Overland flow was greater weight in 2010/2011 year due to the occurrence of greater intense rainfall events. Specifically, in 2009/2010 hydrological year, the participation of the base flow in total runoff was greater for $\mathrm{MFO}$, with $\mathrm{BF} / \mathrm{R}$ ratio of about $76.8 \%$, which means a lesser contribution of overland flow to total runoff (OF/R relation of $23.2 \%$ ).
In $\mathrm{LCW}$ as a whole, these values were $67.7 \%$ and $32.3 \%$ for $\mathrm{BF} / \mathrm{R}$ and $\mathrm{DR} / \mathrm{R}$, respectively. This same behavior was observed for 2010/2011 hydrological year, in which base flow contribution to runoff $(\mathrm{BF} / \mathrm{R})$ in the $\mathrm{MFO}$ was $62.9 \%$, whereas, the contribution of overland flow in the total runoff $(\mathrm{OF} / \mathrm{R})$ was $37.1 \%$. In $\mathrm{LCW}$, for the same hydrological year, there were values of $57.6 \%$ and $42.4 \%$ to $\mathrm{BF} / \mathrm{R}$ and $\mathrm{DR} / \mathrm{R}$, respectively. These results demonstrate the importance of Atlantic Forest for surface hydrology in relation to pasture, offering a greater protection for the soil under a steep topography, reducing the occurrence of flash floods and sediment transport.

The coefficients of the recession $(\alpha)$, in absolute values, were lesser for $\mathrm{LCW}$ than $\mathrm{MFO}$, in both rainy seasons (0.0028 against 0.0132 and 0.0042 against 0.0057 , respectively, for 2009/2010 and 2010/2011 hydrologic years). As the decrease in flow rate is exponential (Equation 4), the greater $\alpha$ in absolute values at MFO means that this catchment drains water stored more slowly into the saturated zone providing greater streamflow during the driest period of the year. Based on these coefficients, it is possible to conclude that the groundwater system under MFO conditions has greater ability to control the baseflow. Given that $38 \%$ of LCW area is occupied by degraded pasture (Figure 1), the hydrological indicators have shown that MFO has better capabilities for natural regularization of streamflow, thus, generating a more stable groundwater flow system.

Viola et al. (2013) simulated the hydrological impacts in four watersheds with similar climate and soil properties in the Grande River basin, and concluded that differences in runoff components within these watersheds are mainly linked to land-use differences and that the greatest contributions of overland flow were found in watersheds with greater area occupied by agriculture and pasture. These types of land-use produce more overland flow than forested areas because cultivated soils and pasture tend to suffer more physical degradation, thus affecting their infiltration capacity.

Table 2: Hydrological indicators for LCW and MFO in the hydrological years of 2009/2010 and 2010/2011.

\begin{tabular}{|c|c|c|c|c|c|c|c|c|}
\hline \multirow{2}{*}{ Hydrological Year } & \multirow{2}{*}{ Sites } & $P$ & $\mathrm{R}$ & $\mathrm{BF}$ & OF & \multirow{2}{*}{$\mathrm{BF} / \mathrm{R}(\%)$} & \multirow{2}{*}{ OF/R (\%) } & \multirow{2}{*}{$\begin{array}{c}a \\
\left(\text { day }^{-1}\right)\end{array}$} \\
\hline & & ................. & ............ & )$\ldots \ldots \ldots$ & 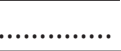 & & & \\
\hline $2009 / 2010$ & \multirow{2}{*}{ LCW } & 2180 & 1250 & 846 & 404 & 67.7 & 32.3 & 0.0028 \\
\hline $2010 / 2011$ & & 2750 & 1385 & 798 & 587 & 57.6 & 42.4 & 0.0042 \\
\hline 2009/2010 & \multirow{2}{*}{ MFO } & 2180 & 1022 & 785 & 237 & 76.8 & 23.2 & 0.0132 \\
\hline $2010 / 2011$ & & 2750 & 1188 & 747 & 441 & 62.9 & 37.1 & 0.0057 \\
\hline
\end{tabular}

P: precipitation; R: runoff; BF: base flow; OF: over land flow; a: recession coefficient. 
Alvarenga et al. (2016) evaluated the effects of land cover changes on the LCW hydrology using the Distributed Hydrology-Soil-Vegetation Model (DHSVM), analyzing the effects of hypothetical land-use change scenarios on the hydrological cycle. This study suggested that high and low flows regimes are affected by land cover scenario changes. Their results also suggest that forests consume more water than pasture, but the maintenance of forest covering in the watershed is required for soil and water conservation, reducing the impacts from soil erosion on water yield and its quality.

Since areas previously occupied by Atlantic Forest are currently occupied by low productivity pastures (Salemi et al., 2013), studies focusing on soil and water conservation and ecological services are urgently needed in Mantiqueira Range region. It is important to stress that these kind of studies are scarce and the influence of land-use on porosity and, consequently, water dynamics in soils need to be better understood in the region from a hydropedology point of view.

Our results are very relevant for the Mantiqueira Range region, as it demonstrates the importance of the Atlantic Forest to be preserved at upper montane forested watersheds, likely reducing impacts from climate changes, and mainly those that affect baseflow dynamics, and therefore, affecting water resources availability.

\section{CONCLUSIONS}

Areas with high to moderate drainable porosity values are associated with native forest fragments as land-use, demonstrating the importance of the Atlantic Forest in the groundwater recharge process at the Mantiqueira Range region. The study of soil images provided useful supporting information on the soil pore system and along with hydrological properties of the watershed helped in understanding the processes of water recharge. The great contribution of native forest to base flow indicates better conditions to water infiltration and, consequently, and to recharge the groundwater system that resulted in a greater base flow. The soil drainable porosity results in a microcatchment entirely covered by native forest showed that these areas have better conditions to transmit water to the aquifer, contributing to base flow during drier periods and producing streamflows more controlled by the groundwater system. This study indicates that soil drainable porosity associated with land-use is related to the dynamic nature of the hydropedological behavior of the watershed.

\section{ACKNOWLEDGMENTS}

This work was supported by the FAPEMIG (grant numbers 588 - CAG PPM - 00132/14 and PPM VIII - 7114), CNPq (grant number 157642/2015-1) and CAPES.

\section{REFERENCES}

ADHIKARI, K. et al. Constructing a soil class map of Denmark based on the FAO legend using digital techniques. Geoderma, 214-215:101-113, 2014.

ALVARENGA, C. C. et al. Índice de qualidade do solo associado à recarga de água subterrânea (IQS RA) na Bacia Hidrográfica do Alto Rio Grande, MG. Revista Brasileira de Ciência do Solo, 36(5):1608-1619, 2012.

ALVARENGA, L. A. et al. Assessment of land cover change on the hydrology of a Brazilian headwater watershed using the Distributed Hydrology-Soil-Vegetation Model. Catena, 143:7-17, 2016.

ÁVILA, L. F. et al. Partição da precipitação pluvial em uma microbacia hidrográfica ocupada por Mata Atlântica na Serra da Mantiqueira, MG. Ciência Florestal, 24(3):583595, 2014.

BARNES, B. S. The structure of discharge recession curves. Transactions of American Geophysical Union, 20(2):721-725, 1939.

BESKOW, S. et al. Soil erosion prediction in the Grande River Basin, Brazil using distributed modeling. Catena, 79(1):4959, 2009.

BEUTLER, A. N. et al. Retenção de água em dois tipos de Latossolo sob diferentes usos. Revista Brasileira de Ciência do Solo, 26(3):829-834, 2002.

BONELL, M. et al. The impact of forest use and reforestation on soil hydraulic conductivity in the Western Ghats of India: Implications of surface and sub-surface hydrology. Journal of Hydrology, 391(1-2):47-62, 2010.

BROWN, R. A.; MCDANIEL, P.; GESSLER, P. E. Terrain attribute modeling of volcanic ash distributions in northern Idaho. Soil Science Society of America Journal, 76(1):179-187, 2012.

BUOL, S. W. et al. Soil Genesis and Classification. WileyBlackwell, Ames, lowa. 2011. 534 p.

CASTRO, S. S. et al. Micromorfologia do Solo: Bases e aplicações. In: CURI, N. et al. Tópicos em ciência do solo. Viçosa: Sociedade Brasileira de Ciência do Solo, 2003, p. 107-164. 
COELHO, C. A. et al. The 2014 southeast Brazil austral summer drought: Regional scale mechanisms and teleconnections. Climate Dynamics, 46(11):3737-3752, 2016.

COLOMBO, A. F.; JOLY, C. A. Brazilian Atlantic Forest lato sensu: The most ancient Brazilian forest, and a biodiversity hotspot, is highly threatened by climate change. Brazilian Journal of Biology, 70(3):697-708, 2010.

CONRAD, O. et al. System for Automated Geoscientific Analyses (SAGA) v. 2.1.4. Geoscientific Model Development, 8:1991-2007.

DEWANDEL, B. et al. Evaluation of aquifer thickness by analysing recession hydrographs. Application to the Oman ophiolite hard-rock aquifer. Journal of Hydrology, 274 (1-4):248-269, 2003.

DURÃES, M. F.; MELLO, C. R. Groundwater recharge behavior based on surface runoff hydrographs in two basins of the Minas Gerais State. Revista Ambiente \& Água, 8(2):5766, 2013.

GERMER, S. et al. Influence of land-use change on near-surface hydrological processes: Undisturbed forest to pasture. Journal of Hydrology, 380(3-4):473-80, 2010.

HENGL, T. Finding the right pixel size. Computers \& Geosciences, 32(9):1283-1298, 2006.

HINGRAY, B.; PICOUET, C.; MUSY, A. Hydrology: A science for engineers. CRC Press, Boca Raton, 2014. 592p.

JASIEWICZ, J.; STEPINSKI, T. Geomorphons: A pattern recognition approach to classification and mapping of landforms. Geomorphology, 182(1):147-156, 2013.

LIBOHOVA, Z. et al. Geomorphons: Landform and property predictions in a glacial moraine in Indiana landscapes. Catena, 142:66-76, 2016.

LIN, H. Earth's critical zone and hydropedology: Concepts, characteristics, and advances. Hydrology and Earth Systems Science, 14(1):25-45, 2010.

LIN, H. Hydropedology: Addressing fundamentals and building bridges to understand complex pedologic and hydrologic interactions. In: LIN, H. Hydropedology: Synergistic Integration of Soil Science and Hydrology. Academic Press, 2012. p.3-39.

MCBRATNEY, A. B.; SANTOS, M. L. M.; MINASNY, B. On digital soil mapping. Geoderma, 117(1-2):3-52, 2003.
MCKAY, J. et al. Evaluation of the transferability of a knowledgebased soil-landscape model. In: BOETTINGER, J. L. et al. Digital soil mapping: Bridging research, environmental application, and operation. London: Springer, 2010, p.165-177.

MELLO, C. R. et al. Predição da porosidade drenável e disponibilidade de água para Cambissolos da microrregião Campos das Vertentes, MG. Pesquisa Agropecuária Brasileira, 37(9):1319-1324, 2002.

MELLO, C. R. et al. Sea surface temperature (SST) and rainfall erosivity in the Upper Grande River Basin, Southeast Brazil. Ciência e Agrotecnologia, 36(1):53-59, 2012.

MELLO, C. R.; CURI, N. Hydropedology. Ciência e Agrotecnologia, 36(2):137-146, 2012.

MENEZES, M. D. et al. Dinâmica hidrológica de duas nascentes, associada ao uso do solo, características pedológicas e atributos físico-hídricos na sub-bacia hidrográfica do Ribeirão Lavrinha - Serra da Mantiqueira (MG). Scientia Forestalis, 37(82):175-184, 2009.

MENEZES, M. D. et al. Digital soil mapping approach based on fuzzy logic and field expert knowledge. Ciência e Agrotecnologia, 37(4):287-298, 2013.

MENEZES, M. D. et al. Solum depth spatial prediction comparing conventional with knowledge-based digital soil mapping approaches. Scientia Agricola, 71(4):316-323, 2014.

MURPHY, C. P. Thin section preparation of soil and sediments. Berkhamsted: A.B. Academic Publications, 1986. 149 p.

MYERS, N. et al. Biodiversity hotspots for conservation priorities. Nature, 403:853-858, 2000.

NETELER, M.; MITASOVA, H. Open source GIS: A GRASS GIS approach. New York: Springer, 2008. 420p.

OLIVEIRA FILHO, A. T. et al. Definição e delimitação de domínios e subdomínios das paisagens naturais do estado de Minas Gerais. In: SCOLFORO, J. R.; CARVALHO, L. M. T. (Ed.). Mapeamento e Inventário da Flora e dos Reflorestamentos de Minas Gerais. Lavras: UFLA, 2006. cap. 1, p.21-35.

PIETOLA, L.; HORN, R.; YLI-HALLA, M. Effects of trampling by cattle on the hydraulic and mechanical properties of soil. Soil \& Tillage Research, 82(1):99-108, 2005.

PINTO, L. C. et al. Water quality index in two land use situations in the Mantiqueira Range. Ciência e Agrotecnologia, 37(4):338-342, 2013. 
PINTO, L. C. et al. Role of inceptisols in the hydrology of mountainous catchments in Southeastern Brazil. Journal of Hydrologic Engineering, 2015a. Available in: <http://ascelibrary.org/doi/abs/10.1061/(ASCE)HE.19435584.0001275 >. Access in: August, 21, 2016.

PINTO, L. C. et al. Micromorphology and pedogenesis of mountainous inceptisols in the Mantiqueira range (MG). Ciência e Agrotecnologia, 39(5):455-462, 2015 b.

PINTO, L. C. et al. Spatial prediction of soil-water transmissivity based on fuzzy logic in a Brazilian headwater watershed. Catena, 143:26-34, 2016.

PRICE, K.; JACKSON, C. R.; PARKER, A. J. Variation of surficial soil hydraulic properties across land uses in the southern Blue Ridge Mountains, North Carolina, USA. Journal of Hydrology, 383(3-4):256-268, 2010.

RAWLS, W. J. et al. Effect of soil organic carbono on soil water retention. Geoderma, 116(1-2):61-76, 2003.

RESENDE, M. et al. Pedologia: Base para distinção de ambientes. 6. ed. Lavras: Editora UFLA, 2014, 378p.

RIBEIRO, M. C. et al. Brazilian Atlantic forest: how much is left and how is the remaining forest distributed? Implications for conservation. Biological Conservation, 142(6):11411153, 2009.

SALEMI, L. F. et al. Land-use change in the Atlantic rainforest region: Consequences for the hydrology of small catchments. Journal of Hydrology, 499:100-109, 2013.

$\mathrm{SHI}$, X. et al. Integrating different types of knowledge for digital soil mapping. Soil Science Society of America Journal, 73(5):1682-1692, 2009.

SILVA, R. F. G.; BACELLAR, L. A. P.; FERNANDES, K. N. Estimativa de parâmetros de aquíferos através do coeficiente de recessão em áreas de embasamento cristalino de Minas Gerais. Revista Escola de Minas, 63(3):465-471, 2010.

SILVA, B. M.; SANTOS, W. J. R.; MARQUES, J. J. Levantamento detalhado dos solos da Fazenda Muquém/UFLA. Lavras: UFLA, 2014. 76p.

SILVA, S. H. G. et al. Retrieving pedologist's mental model from existing soil map and comparing data mining tools for refining a larger area map under similar environmental conditions in Southeastern Brazil. Geoderma, 267: 65-77, $2016 a$.
SILVA, S. H. G. et al. Geomorphometric tool associated with soil types and properties spatial variability at watersheds under tropical conditions. Scientia Agricola, 73(4):363370, $2016 \mathrm{~b}$.

SILVA, M. A. et al. Predicting runoff risks by digital soil mapping. Revista Brasileira de Ciência do Solo, 40:1-13, 2016c.

STOTT, P. How climate change affects extreme weather events. Science, 352(6293):1517-1518, 2016.

TOBIAŠOVÁ, E. The effect of organic matter on the structure of soils of different land uses. Soil \& Tillage Research, 114(2):183-192, 2011.

TOMA, M. A. et al. Carbon pool ratios as scientific support to field morphology in the differentiation of dark subsurface soil horizons. Scientia Agricola, 72(4):334-342, 2015.

TSUI, C.; CHEN, Z. S.; HSIEH, C. F. Relationships between soil properties and slope position in a lowland rain forest of southern Taiwan. Geoderma, 123(1-2):131-142, 2004.

VAYSSE, K.; LAGACHERIE, P. Evaluating digital soil mapping approaches for mapping GlobalSoilMap soil properties from legacy data in Languedoc-Roussillon (France). Geoderma Regional, 4:20-30, 2015.

VIEIRA, S. A. et al. Estimation of biomass and carbon stocks: The case of the Atlantic Forest. Biota Neotropica, 8(2):21-29, 2008.

VIOLA, M. R. et al. Applicability of the LASH model for hydrological simulation of the Grande River Basin, Brazil. Journal of Hydrologic Engineering, 18(12):1639-1652, 2013.

VIOLA, M. R. et al. Impacts of Land-use changes on the hydrology of the Grande River Basin Headwaters, Southeastern Brazil. Water Resource Management, 28(13):4537-4550, 2014.

VIOLA, M. R. et al. Assessing climate change impacts on Upper Grande River Basin hydrology, Southeast Brazil. International Journal of Climatology, 35(6):1054-1068, 2015.

WIEKENKAMP, I. et al. Changes in measured spatiotemporal patterns of hydrological response after partial deforestation in a headwater catchment. Journal of Hydrology, 542:648661, 2016.

ZHU, A. X. et al. Derivation of soil properties using a Soil Land Inference Model (SoLIM). Soil Science Society of America Journal, 61(2):523-533, 1997. 